\title{
Heterogeneity of soil carbon pools and fluxes in a channelized and a restored floodplain section (Thur River, Switzerland)
}

\author{
E. Samaritani ${ }^{1,2,4, *}$, J. Shrestha ${ }^{3, *}$, B. Fournier ${ }^{1,2,4}$, E. Frossard ${ }^{5}$, F. Gillet ${ }^{2,6}$, C. Guenat ${ }^{2}$, P. A. Niklaus ${ }^{7}$, N. Pasquale ${ }^{8}$, \\ K. Tockner ${ }^{9}$, E. A. D. Mitchell ${ }^{1,2,4}$, and J. Luster ${ }^{3}$ \\ ${ }^{1}$ Swiss Federal Institute for Forest, Snow, and Landscape Research, 1015 Lausanne, Switzerland \\ ${ }^{2}$ Ecole Polytechnique Fédérale de Lausanne, Laboratory of Ecological Systems, 1015 Lausanne, Switzerland \\ ${ }^{3}$ Swiss Federal Institute for Forest, Snow, and Landscape Research, Zürcherstrasse 111, 8903 Birmensdorf, Switzerland \\ ${ }^{4}$ Institute of Biology, University of Neuchâtel, Rue Emile Argand 11, 2000 Neuchâtel, Switzerland \\ ${ }^{5}$ Institute of Agricultural Sciences ETH Zurich, Eschikon 33, 8315 Lindau, Switzerland \\ ${ }^{6}$ Laboratoire Chrono-Environnement, UMR 6249 CNRS, Université de Franche-Comté, 16 route de Gray, \\ 25030 Besançon cedex, France \\ ${ }^{7}$ Institute of Evolutionary Biology and Environmental Studies, University of Zurich, Winterthurerstrasse 190, \\ 8057 Zurich, Switzerland \\ ${ }^{8}$ Institute of Environmental Engineering ETH Zurich, Schaffmattstrasse 6, 8093 Zurich, Switzerland \\ ${ }^{9}$ Leibniz-Institute of Freshwater Ecology and Inland Fisheries (IGB), and Institute of Biology, Freie Universität Berlin, \\ Müggelseedamm 310, 12587, Berlin, Germany \\ *These authors contributed equally to this work.
}

Received: 13 December 2010 - Published in Hydrol. Earth Syst. Sci. Discuss.: 24 January 2011

Revised: 18 May 2011 - Accepted: 19 May 2011 - Published: 6 June 2011

\begin{abstract}
Due to their spatial complexity and dynamic nature, floodplains provide a wide range of ecosystem functions. However, because of flow regulation, many riverine floodplains have lost their characteristic heterogeneity. Restoration of floodplain habitats and the rehabilitation of key ecosystem functions, many of them linked to organic carbon (C) dynamics in riparian soils, has therefore become a major goal of environmental policy. The fundamental understanding of the factors that drive the processes involved in $\mathrm{C}$ cycling in heterogeneous and dynamic systems such as floodplains is however only fragmentary.

We quantified soil organic $\mathrm{C}$ pools (microbial $\mathrm{C}$ and water extractable organic $\mathrm{C}$ ) and fluxes (soil respiration and net methane production) in functional process zones of adjacent channelized and widened sections of the Thur River, NE Switzerland, on a seasonal basis. The objective was to assess how spatial heterogeneity and temporal variability of these pools and fluxes relate to physicochemical soil properties on one hand, and to soil environmental conditions and flood disturbance on the other hand.
\end{abstract}

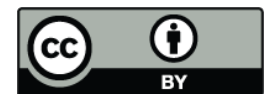

Correspondence to: J. Luster

(joerg.luster@wsl.ch)
Overall, factors related to seasonality and flooding (temperature, water content, organic matter input) affected soil $\mathrm{C}$ dynamics more than soil properties did. Coarse-textured soils on gravel bars in the restored section were characterized by low base-levels of organic $\mathrm{C}$ pools due to low TOC contents. However, frequent disturbance by flood pulses led to high heterogeneity with temporarily and locally increased $\mathrm{C}$ pools and soil respiration. By contrast, in stable riparian forests, the finer texture of the soils and corresponding higher TOC contents and water retention capacity led to high baselevels of $\mathrm{C}$ pools. Spatial heterogeneity was low, but major floods and seasonal differences in temperature had additional impacts on both pools and fluxes. Soil properties and base levels of $\mathrm{C}$ pools in the dam foreland of the channelized section were similar to the gravel bars of the restored section. By contrast, spatial heterogeneity, seasonal effects and flood disturbance were similar to the forests, except for indications of high $\mathrm{CH}_{4}$ production that are explained by long travel times of infiltrating water favoring reducing conditions. Overall, the restored section exhibited both a larger range and a higher heterogeneity of organic $\mathrm{C}$ pools and fluxes as well as a higher plant biodiversity than the channelized section. This suggests that restoration has indeed led to an increase in functional diversity. 


\section{Introduction}

Embracing spatial heterogeneity is a major challenge in ecosystem ecology. The composition, spatial configuration and temporal dynamics of habitat patches determine biodiversity and ecosystem processes. Ecosystems therefore need to be considered as dynamically interacting mosaics rather than homogeneous entities (Ward et al., 1999; Pinay et al., 2002). Floodplains are an ideal model to study spatial and temporal heterogeneity.

Floodplains are defined as low-relief areas that extend from the edge of permanent water bodies to the edge of uplands and are subject to flooding. In their natural state, the interaction between flood dynamics and geomorphic processes create a shifting mosaic of habitat patches (Naiman and Décamps, 1997; Stanford et al., 2005). These hydrogeomorphically distinct patches differ in age, inundation regime, and soil properties, thereby expressing a different productivity, system metabolism, organic matter dynamic, and biotic community composition. These patches can be referred to as "Functional Process Zones" (FPZs) as described by Thorp et al. (2008), although, in the context of the present study we apply the FPZ concept at a smaller scale to hydrogeomorphic patches within a single reach. Furthermore, we extend "functional" to ecological processes rather than to restrict the term to physical functioning of geomorphic and hydrologic forces. In dynamic floodplains, the various FPZs are arranged along distinct succession gradients (Naiman and Décamps, 1997), from recently deposited sand or gravel to mature alluvial forests.

Due to their spatial complexity and dynamic nature, floodplains provide a wide range of ecosystem functions and related services. Because flow alteration is one of the most serious threats to ecological integrity of river-floodplain systems (Tockner et al., 2008), the widespread regulation of the flow regime of large rivers, in particular in Europe and North America has led to the loss of characteristic environmental heterogeneity, biodiversity and associated ecosystem services in many floodplains (Tockner and Stanford, 2002). In the last decades, restoration of floodplain habitats and the consequent rehabilitation of key ecosystem functions has become a major goal of environmental policy, and concurrently scientific approaches to evaluate its success have been put forward (Henry et al., 2002; Palmer et al., 2005; Woolsey et al., 2007). Motivated to a large extent by flood protection, restoration is achieved, e.g., by widening the main river channel through the removal of embankments and by the setback of flood levees (Rohde et al., 2005; van Stokkom et al., 2005).

Ecosystem services such as provision of plant and animal resources, removal and/or degradation of pollutants, nutrient retention, and carbon $(\mathrm{C})$ storage are tightly linked to organic C dynamics in riparian soils (Hill and Cardaci, 2004; Wilson et al., 2011). Although the need for a fundamental understanding of the factors that drive the processes in- volved in $\mathrm{C}$ cycling in heterogeneous and dynamic systems such as floodplains is recognized, knowledge is still fragmentary (Pacific et al., 2008; Zehetner et al., 2009). There have been an increasing number of publications in recent years on abundance and community structure of microorganisms in riparian soils (e.g., Rinklebe and Langer, 2006; Unger et al., 2009), but still little information is available on bioavailable and mobile soil organic carbon (Bishop et al., 1994; Hill and Cardaci, 2004). The heterogeneity of soil-atmosphere exchange of $\mathrm{CO}_{2}$ and methane has been addressed previously (e.g. Pulliam 1993; Gulledge and Schimel, 2000; Pacific et al. 2008). However, combined studies addressing both "active" carbon pools and gas exchange as proxies of different aspects of soil functionality have been rare.

In this study we quantify $\mathrm{C}$ dynamics in adjacent channelized and widened sections of the Thur River, NE Switzerland. This is the main test site of the interdisciplinary project RECORD (http://www.cces.ethz.ch/projects/nature/ Record; Linde et al., 2011; Pasquale et al., 2011; Schneider et al., 2011). The site is composed of three different types of FPZs: (i) frequently flooded, dynamic patches in the restored section, (ii) mature, stable alluvial forests that are flooded once or twice a year in the restored section, and (iii) geomorphologically homogeneous pasture in the channelized section. The objective was to assess spatial heterogeneity (among and within FPZs) and temporal variability of selected soil organic C pools (microbial $\mathrm{C}$ and water extractable organic $\mathrm{C}$ ) and fluxes (soil respiration and methane fluxes) and how they relate to physicochemical soil properties on one hand, and to soil environmental conditions and flood disturbance on the other hand. In particular, we wanted to test the hypotheses that (i) frequent disturbance by flood pulses in the dynamic FPZs affects the $\mathrm{C}$ pools and fluxes temporarily and locally and (ii) such effects are an essential precondition to achieve a broad spectrum of conditions and processes supporting a large variety of organisms and, thus biodiversity. Our motivation was to better understand $\mathrm{C}$ dynamics in the different types of floodplain FPZs, and, as a consequence, how differences in floodplain structure, in particular between regulated and restored river sections, may affect related ecosystem services such as carbon storage and habitat provision.

\section{Test site}

The Thur River (catchment area: $1750 \mathrm{~km}^{2}$ ) originates in the limestone formation of the Mount Säntis region (2500 m a.s.1.), crosses the Swiss Plateau, and enters the Rhine River at $345 \mathrm{~m}$ a.s.l. The river exhibits a flashy flow regime due to the absence of reservoirs and natural lakes. Maximum, mean, and minimum flow rates are 1130, 47, and $2 \mathrm{~m}^{3} \mathrm{~s}^{-1}$, respectively (recording period 1904-2005: http: //www.hydrodaten.admin.ch/d/2044.htm). Flood events occur mainly during the snowmelt period in spring, and heavy 


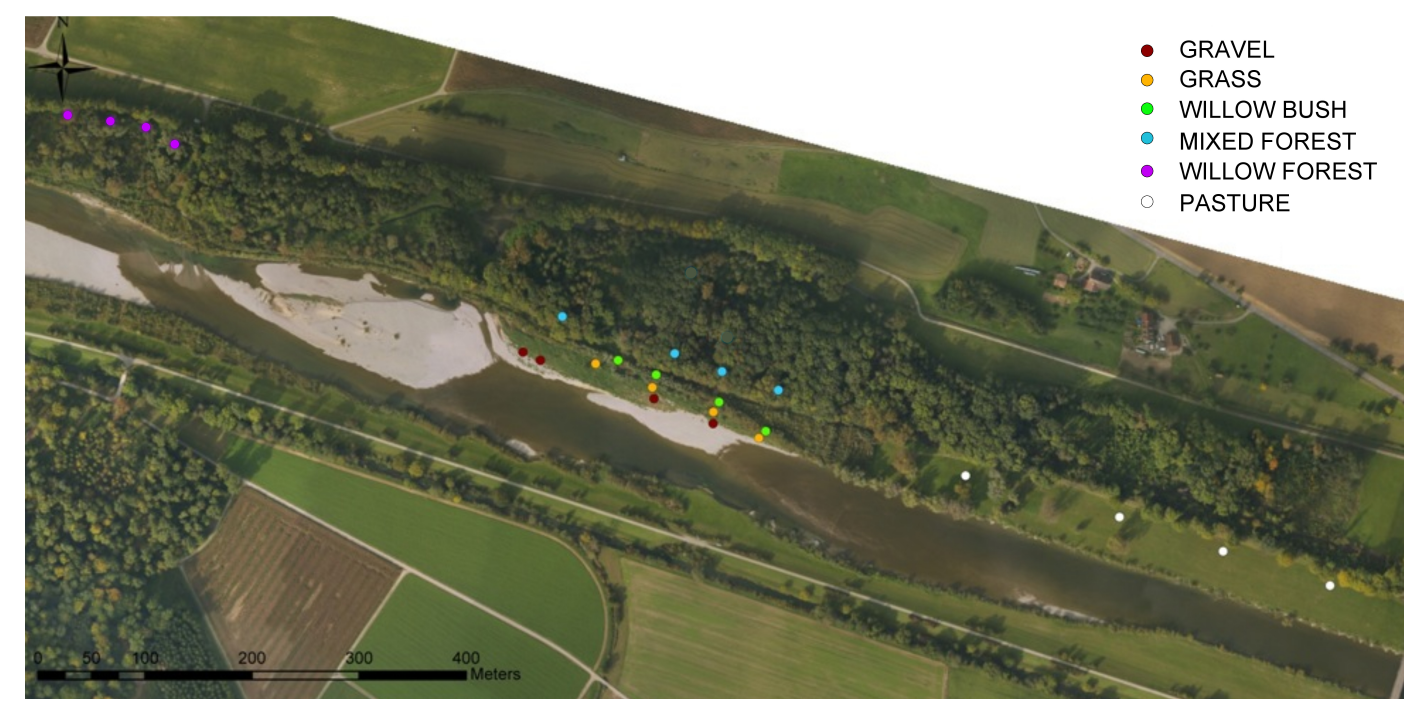

Fig. 1. Aerial view of the Thur River test site near Niederneunforn (North-Eastern Switzerland) showing the different plots for each of the six functional process zones.

rainfall events in summer and autumn. The formerly braided river was channelized in the 1890 s to protect the river valley against flooding. In the 1970s, a plan to concurrently improve the flood protection and ameliorate the ecological state of the river corridor was elaborated. Since 1993, several $1-3 \mathrm{~km}$ long river sections were widened to allow the formation of alternating gravel bars and to increase hydrological connectivity between the main channel and its riparian zone. One of these sections is the test site. Basic data on the chemical quality of the Thur River and the adjacent alluvial aquifers can be found in Hoehn and Scholtis (2011).

The test site is located in the river corridor at Niederneunforn (Canton Thurgau, $8^{\circ} 77^{\prime} 12^{\prime \prime} \mathrm{E}$; $47^{\circ} 59^{\prime} 10^{\prime \prime} \mathrm{N}$ ), where a $2 \mathrm{~km}$ long section was restored in 2002. The main channel was widened from $50 \mathrm{~m}$ to $110 \mathrm{~m}$ by removing the foreland in front of the levees. In addition, the levees were lowered in some places to reconnect the old alluvial forest with the river during high floods. The newly exposed banks were partly reinforced by tree trunks, and additionally by planting a strip of willow saplings. In the widened river channel, discharge fluctuations and sedimentation have led to the evolution of a dynamic succession of gravel bars. At the test side, this morphodynamic has been monitored using innovative methodology (Pasquale et al., 2011), and the subsurface structure of the gravel bars was characterized with the help of geophysical methods (Linde et al., 2011; Schneider et al., 2011). The mean annual precipitation at the test site is $908 \mathrm{~mm}$ and the average monthly temperature ranges from $0.9^{\circ} \mathrm{C}$ in January to $19.0^{\circ} \mathrm{C}$ in July (study period; http://gate.meteoswiss.ch/idaweb).

Six FPZs were identified based on vegetation, distance to the river and topography (Fig. 1): five in the restored section and one in an adjacent channelized section upstream. As a re- sult of their topographic position, these FPZs are flooded at different river discharge levels and are exposed to different flooding frequencies and durations (Table 1, Fig. 2). Starting from the riverbed, the first FPZ (GRAVEL) is a mosaic of bare gravel and patchy vegetation covering on average $33 \%$ of the ground. It is frequently inundated and has very little fine soil. The second FPZ (GRASS) is gravel covered by up to $1 \mathrm{~m}$ of fine sediments that were trapped mainly by the dominant grass Phalaris arundinacea. This plant tolerates both wet and dry conditions characteristic of soils in pulse-flooded riparian systems (Foster and Wetzel, 2005). The third FPZ (WILLOW BUSH) comprises the banks composed of older sediments with shrubby vegetation dominated by planted Salix viminalis. Other willow species were also present, and the relatively dense understory was dominated by Rubus sp. and various grass species. This strip varies in width from 5 to $10 \mathrm{~m}$, and the study plots were selected in the middle of the bank slope. The last two FPZs, MIXED FOREST and WILLOW FOREST, are forest communities characteristic of floodplains with a deep and shallow average groundwater level, respectively (Schmider et al., 2003). MIXED FOREST is dominated by Acer pseudoplatanus and Fraxinus excelsior trees and the understory was dominated by Allium ursinum and Ranunculus ficaria in spring and Carex pendula and Rubus spp. later in the year. The North side of this FPZ is bordered by a side channel that drains the neighbouring agricultural hill slope. The WILLOW FOREST FPZ at the downstream end of the restored section is dominated by mature Salix alba trees. The understory was dominated by $R$. ficaria in spring, and by very dense and monospecific patches of Urtica dioica later in the year. The northern border of this part of the forest is formed by an old side channel that has partly silted up, but still drains 
Table 1. Hydro-geological characteristics of the six functional process zones of the test site in the Thur River floodplain, Switzerland.

\begin{tabular}{|c|c|c|c|c|c|c|c|}
\hline & & GRAVEL & GRASS & $\begin{array}{c}\text { WILLOW } \\
\text { BUSH }\end{array}$ & $\begin{array}{l}\text { MIXED } \\
\text { FOREST }\end{array}$ & $\begin{array}{l}\text { WILLOW } \\
\text { FOREST }\end{array}$ & PASTURE \\
\hline Maximum elevation within the plots 1 & m a.s.l. & 373.0 & 373.4 & 373.6 & 374.9 & 372.5 & 374.7 \\
\hline Minimum elevation within the plots ${ }^{1}$ & m a.s.l. & 371.8 & 372.5 & 372.5 & 373.6 & 371.6 & 374.2 \\
\hline $\begin{array}{l}\text { Minimum river discharge for flooding } \\
\text { lowest lying plot } \\
\text { Minimum river discharge for flooding }\end{array}$ & $\mathrm{m}^{3} \mathrm{~s}^{-1}$ & 75 & 125 & 150 & 650 & 400 & 400 \\
\hline highest lying plot $^{2}$ & $\mathrm{~m}^{3} \mathrm{~s}^{-1}$ & 180 & 250 & 270 & $>800$ & 400 & 400 \\
\hline Flooding frequency ${ }^{3}$ & times year $^{-1}$ & $>10$ & $>10$ & $4-6$ & $1-2$ & $1-2^{4}$ & $1-2$ \\
\hline Flooding duration per event ${ }^{3}$ & days & $<1$ to 14 & $<1$ to 14 & $\leq 1$ & $<1$ & $<1^{4}$ & $<1$ \\
\hline
\end{tabular}

1 As measured in May 2010.

2 Estimated from inundation maps produced by digital terrain modeling based on river cross section measurements.

3 Approximated using the river discharge data for the years 2007 to 2009 and the minimum river discharge for flooding half of the plots within an FPZ.

${ }^{4}$ In WILLOW FOREST more and longer inundation events can occur due to ponding of precipitation or delayed drainage.

the hill slope and collects back flow water from River Thur. The PASTURE FPZ lies in the channelized section and is used by farmers for grazing and grass fodder production. The plant community was typical of managed grasslands and dominated by grass species (mainly Elymus repens, Dactylis glomerata, and Arrhenatherum elatius) and forbs such as Taraxacum officinale and Trifolium repens.

In this study, we have considered the first three FPZs in the restored section as "dynamic" FPZs, and the two forest FPZs as "stable" FPZs. In each FPZ, four plots of eight-meter diameter were selected. The upstream half-circle was used for vegetation mapping and gas sampling while the downstream half-circle was used for destructive soil sampling.

\section{Methods}

\subsection{Vegetation}

In each plot, all vascular plant species were recorded, and cover was estimated using Braun-Blanquet codes (BraunBlanquet, 1964). Observations were repeated six times during the 2008 growing season and species richness was calculated from the combined data set.

\subsection{Soil sampling}

Topsoil sampling was carried out in April and October 2008, and in January, April and August 2009. The first sampling served to obtain basic background information on physicochemical soil properties, while the other four samplings were used for detailed measurements of $\mathrm{C}$ pools and fluxes. In each plot, three cores $(6.5 \mathrm{~cm}$ diameter $\times 10 \mathrm{~cm}$ depth $)$ were pooled. In GRAVEL plots, soil was collected from pits. One half of the field moist soil was sieved $(2 \mathrm{~mm})$ and stored at $4{ }^{\circ} \mathrm{C}$ while the other half was dried $\left(40^{\circ} \mathrm{C}, 48 \mathrm{~h}\right)$ and then sieved at $2 \mathrm{~mm}$. In May 2008, two $1 \mathrm{~m}$ long soil cores were

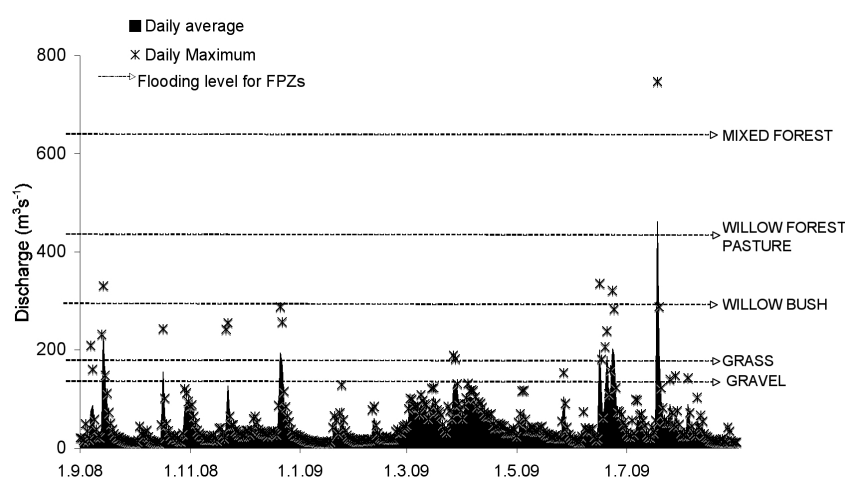

Fig. 2. Daily average and maximum discharge of the Thur River at the test site. Minimum discharge required for inundation is different for each functional process zone (FPZ) and the flooding level shown here is the average elevation of the four plots for each FPZ.

taken with a drill corer from two plots of each FPZ except GRAVEL where coarse gravel prevented the use of the equipment. Each core was split into $20 \mathrm{~cm}$ long segments, and the samples were dried and sieved as described before.

\subsection{Basic soil properties}

Soil texture of dried samples was measured using the pipette method (Gee and Bauder, 1986) after removing organic matter with hydrogen peroxide and dispersing with sodium hexametaphosphate. Grain size classes were defined as clay $(<2 \mu \mathrm{m})$, silt $(2-63 \mu \mathrm{m})$ and sand $(63 \mu \mathrm{m}-2 \mathrm{~mm})$. Soil $\mathrm{pH}$ was measured in a 1:2 slurry of dried soil in $0.01 \mathrm{M}$ calcium chloride after 30 min equilibration. Total $\mathrm{N}$ and organic and inorganic $\mathrm{C}$ contents of finely ground, dried soils were determined as described by Walthert et al. (2010). For Olsen P as a proxy of available $\mathrm{P}$, dried soil was extracted for $30 \mathrm{~min}$ at $25^{\circ} \mathrm{C}$ with $0.5 \mathrm{M}$ sodium hydrogen carbonate at $\mathrm{pH} 8.5$ with 
a soil to extractant ratio of 1:20. The extracts were filtered through Schleicher and Schuell 07901/2 and the extracted phosphate measured colorimetrically using the molybdenum blue method (Kuo, 1996).

\subsection{Soil environmental conditions}

Soil temperature $(T)$ at $5 \mathrm{~cm}$ depth was measured in the centre of each plot during the entire observation period $(30 \mathrm{~min}$ resolution; TidBit v2 temperature loggers, onset, Bourne, MA, USA). The temperatures recorded at the time of the soil samplings were used in this study. Gravimetric Water Content (WC) was determined as weight loss upon drying $20 \mathrm{~g}$ of fresh soil at $105^{\circ} \mathrm{C}$ for $24 \mathrm{~h}$. The elevation of the plots was measured in May 2010 by triangulation. The minimum river discharge required for flooding a plot was estimated from inundation maps for different river discharge levels as produced by a 2-D hydrodynamic model (details see Pasquale et al., 2011). The estimate of days after last inundation (LI) was based on the minimum discharge value for a given plot and the date at which discharge fell below this threshold.

\subsection{Carbon pools}

Water extractable organic carbon (WEOC) was extracted from dried soils with $10 \mathrm{mM}$ calcium chloride at a soil:extractant ratio of 1:2 for $10 \mathrm{~min}$ on an end-over-end shaker (Embacher et al., 2007). The soil slurries were then centrifuged for $10 \mathrm{~min}$ at $1335 \mathrm{~g}$ and filtered through a $0.45 \mu \mathrm{m}$ membrane filter. The filtered extracts were measured for non-purgeable organic C (NPOC) using a TOC analyzer (Formacs HT, Skalar Analytical, Breda, The Netherlands). Water extractable organic matter of soils, measured as WEOC, is an operationally defined proxy of dissolved organic matter in the soil solution, playing important roles as substrate of microorganisms and as transport agent (Embacher et al., 2007). Although WEOC also represents part of the microbial biomass when extracted from dried soils as in the present study (Embacher et al., 2007), we consider this pool mainly as proxy of available substrate.

Microbial biomass C (MC) was determined by the chloroform fumigation extraction method (Beck et al., 1997). Fresh soil samples corresponding to $10 \mathrm{~g}$ dry mass were placed in a desiccator containing chloroform. The desiccator was evacuated and left in the dark for $24 \mathrm{~h}$. These fumigated soil samples and another set of fresh soil samples were extracted for one hour with $0.5 \mathrm{M}$ potassium sulphate at a 1:5 soil to extractant ratio. The extracts were filtered $(0.45-\mu \mathrm{m})$ and frozen. The NPOC in these samples was measured using a TOC analyzer (TOC-V CPH/CPN, Shimadzu, Kyoto, Japan). Microbial $\mathrm{C}$ was calculated as

$\mathrm{MC}=\frac{\left(\mathrm{C}_{\text {fumigated }}-\mathrm{C}_{\text {unfumigated }}\right)}{k_{\mathrm{EC}}}$ where $\mathrm{C}_{\text {fumigated }}$ and $\mathrm{C}_{\text {unfumigated }}$ are the NPOC contents of chloroform-fumigated and unfumigated samples, and $k_{\mathrm{EC}}=$ 0.45 corrects for extraction efficiency (Beck et al., 1997).

\subsection{Carbon fluxes}

For soil respiration (SR) and methane flux (MF) measurements, PVC rings with $30 \mathrm{~cm}$ diameter and $30 \mathrm{~cm}$ height (20 $\mathrm{cm}$ below and $10 \mathrm{~cm}$ above surface) were installed in each plot. Immediately before sampling, vegetation within the rings was clipped and the chamber closed with an airtight lid. Headspace air samples were collected after 5, 25 and $45 \mathrm{~min}$, injected into pre-evacuated exetainers, and analyzed for $\mathrm{CH}_{4}$ and $\mathrm{CO}_{2}$ using a gas chromatograph with a flame ionization detector (Agilent 6890, Santa Clara, USA). Soil-atmosphere $\mathrm{CH}_{4}$ and $\mathrm{CO}_{2}$ exchange were calculated by linear regression of concentration against sampling time. Temperature dependence of SR was modeled for each FPZ using an exponential equation (Buchmann, 2000)

$y=a \cdot e^{(b \cdot T)}$

where $a$ and $b$ are regression coefficients, and $T$ is the temperature at the time of gas sampling. $Q_{10}$ values were calculated as

$Q_{10}=e^{(10 \cdot b)}$

Soil respiration normalised to a reference temperature of $10^{\circ} \mathrm{C}$ (SR_T10) was calculated according to Doering et al. (2011) as

$\mathrm{SR} \_\mathrm{T} 10=\mathrm{SR} \cdot e^{(b(10-T))}$

Soil respiration is an indicator of the actual biological activity at the sampling site including both microbial and root respiration. Positive methane flux indicates net methane production while negative flux indicates net methane consumption in the soil.

\subsection{Statistical analyses}

Differences in the soil physicochemical properties among the sites were tested using one-way analysis of variance (ANOVA, SPSS 17, SPSS Inc.). Interactive effects of time and FPZ were tested by one-way repeated measures ANOVA. Post hoc tests were carried out using Tukey HSD if homogeneity of variance could be assumed or else using Games Howell (Field, 2005). Principal component analysis (PCA) was carried out for soil physicochemical properties measured in the soil profile samples. Redundancy analyses (RDA) were carried out for $\mathrm{C}$ pools and fluxes as multivariate response to soil properties and environmental conditions. The RDA triplot was projected using scaling method 2 (Kindt and Coe, 2005). The program $\mathrm{R}$ ( $\mathrm{R}$ Development Core Team, 2010) with package vegan (Oksanen et al., 2010) was used for PCA and RDA. 
Table 2. Mean \pm standard deviation of vegetation characteristics and physicochemical soil properties in the six functional process zones $(n=4)$ of the test site in the Thur River floodplain, Switzerland. Soil properties are for the top $10 \mathrm{~cm}$ of soil. Values with different superscript letters in the same row are significantly different $(P<0.05$; Tukey post-hoc test).

\begin{tabular}{|c|c|c|c|c|c|c|c|}
\hline & Units & GRAVEL & GRASS & $\begin{array}{c}\text { WILLOW } \\
\text { BUSH }\end{array}$ & $\begin{array}{l}\text { MIXED } \\
\text { FOREST }\end{array}$ & $\begin{array}{l}\text { WILLOW } \\
\text { FOREST }\end{array}$ & PASTURE \\
\hline Species richness & & $55.0 \pm 13.6^{\mathrm{bc}}$ & $41.5 \pm 11.2^{\mathrm{c}}$ & $79.8 \pm 8.8^{\mathrm{a}}$ & $50.8 \pm 4.5^{b c}$ & $41.5 \pm 3.1^{c}$ & $67.7 \pm 3.5^{\mathrm{ab}}$ \\
\hline $\mathrm{pH}$ & & $7.6 \pm 0.1^{\mathrm{a}}$ & $7.4 \pm 0.1^{\mathrm{a}}$ & $7.5 \pm 0.0^{\mathrm{a}}$ & $7.5 \pm 0.0^{\mathrm{a}}$ & $7.4 \pm 0.0^{\mathrm{a}}$ & $7.5 \pm 0.0^{\mathrm{a}}$ \\
\hline Sand & $\mathrm{g} \mathrm{kg}^{-1}$ & $806 \pm 52^{a}$ & $660 \pm 17^{a b c}$ & $442 \pm 90^{b c}$ & $378 \pm 57^{\mathrm{c}}$ & $245 \pm 40^{c}$ & $651 \pm 69^{a b}$ \\
\hline Clay & $\mathrm{g} \mathrm{kg}^{-1}$ & $53 \pm 13^{d}$ & $83 \pm 36^{\mathrm{bcd}}$ & $117 \pm 18^{a b c}$ & $148 \pm 18^{a b}$ & $177 \pm 24^{\mathrm{a}}$ & $78 \pm 16^{\mathrm{cd}}$ \\
\hline Inorganic $\mathrm{C}$ & $\mathrm{g} \mathrm{CaCO}_{3} \mathrm{~kg}^{-1}$ & $355 \pm 25^{b}$ & $385 \pm 18^{\mathrm{ab}}$ & $408 \pm 5^{\mathrm{a}}$ & $390 \pm 6^{\mathrm{a}}$ & $390 \pm 3^{\mathrm{a}}$ & $382 \pm 7^{a b}$ \\
\hline Organic C & $\mathrm{g} \mathrm{kg}^{-1}$ & $10.1 \pm 3.7^{c}$ & $16.3 \pm 5.8^{b c}$ & $17.1 \pm 3.2^{\mathrm{abc}}$ & $21.4 \pm 3.6^{\mathrm{ab}}$ & $24.8 \pm 1.5^{\mathrm{a}}$ & $12.9 \pm 2.9 \mathrm{bc}$ \\
\hline Total N & $\mathrm{g} \mathrm{kg}^{-1}$ & $0.7 \pm 0.2^{\mathrm{c}}$ & $1.0 \pm 0.4^{\mathrm{bc}}$ & $1.1 \pm 0.3^{b c}$ & $1.6 \pm 0.3^{\mathrm{ab}}$ & $1.8 \pm 0.1^{\mathrm{a}}$ & $0.9 \pm 0.2^{\mathrm{c}}$ \\
\hline $\mathrm{C}: \mathrm{N}$ & $\mathrm{gg}^{-1}$ & $15.2 \pm 0.5^{\mathrm{ab}}$ & $16.2 \pm 1.6^{\mathrm{a}}$ & $15.2 \pm 0.7^{\mathrm{ab}}$ & $13.4 \pm 0.6^{\mathrm{b}}$ & $14.0 \pm 0.2^{b}$ & $14.0 \pm 0.4^{b}$ \\
\hline Available P & $\mathrm{mg} \mathrm{kg}^{-1}$ & $24.6 \pm 11.1^{\mathrm{ab}}$ & $35.9 \pm 10.1^{\mathrm{a}}$ & $16.7 \pm 5.5^{b}$ & $14.2 \pm 4.5^{b}$ & $22.3 \pm 7.6^{\mathrm{ab}}$ & $8.3 \pm 4.5^{b}$ \\
\hline
\end{tabular}

\section{Results}

\subsection{Vegetation}

Mean plant species richness was lowest in GRASS and WILLOW FOREST, and highest in WILLOW BUSH (Table 2). Spatial variability was higher in GRAVEL and GRASS than in the other FPZs (Table 3). A principal component analysis of plant species composition and cover revealed that the vegetation in PASTURE and in both forested FPZs was rather similar, while it exhibited completely different characteristics in the three dynamic FPZs (data not shown).

\subsection{Basic soil properties}

All soils were rich in carbonates and, accordingly, had a $\mathrm{pH}$ of about 7.5 (Table 2). In the restored section, soils became more finely textured along a gradient from GRAVEL to WILLOW FOREST. Total organic carbon (TOC) and total nitrogen $(\mathrm{TN})$ contents increased along the same gradient, while the $\mathrm{C} / \mathrm{N}$ was around 15 in all FPZs. Available $\mathrm{P}$ was significantly higher in GRASS than in WILLOW BUSH and MIXED FOREST. Soil properties of PASTURE were similar to GRASS except for a significantly lower available P content. Spatial variability of texture and TOC content were highest in GRAVEL and GRASS, and lowest in the two forest FPZs (Table 3).

Soil texture did not vary much with depth in any of the FPZs (data not shown). TOC and TN contents were also homogenously distributed within the soil profiles except for WILLOW FOREST. There, TOC and TN decreased with depth to $15 \mathrm{~g} \mathrm{C} \mathrm{kg}^{-1}$ and $1.1 \mathrm{~g} \mathrm{~N} \mathrm{~kg}^{-1}$ respectively. Available $\mathrm{P}$ decreased gradually with depth to $7 \mathrm{mg} \mathrm{kg}^{-1}$ in WILLOW FOREST, and to about $5 \mathrm{mg} \mathrm{kg}^{-1}$ in MIXED FOREST and WILLOW BUSH. In GRASS available P did not vary with depth and in PASTURE it first decreased to less than $5 \mathrm{mg} \mathrm{kg}^{-1}$ at $20-40 \mathrm{~cm}$ depth and then increased to

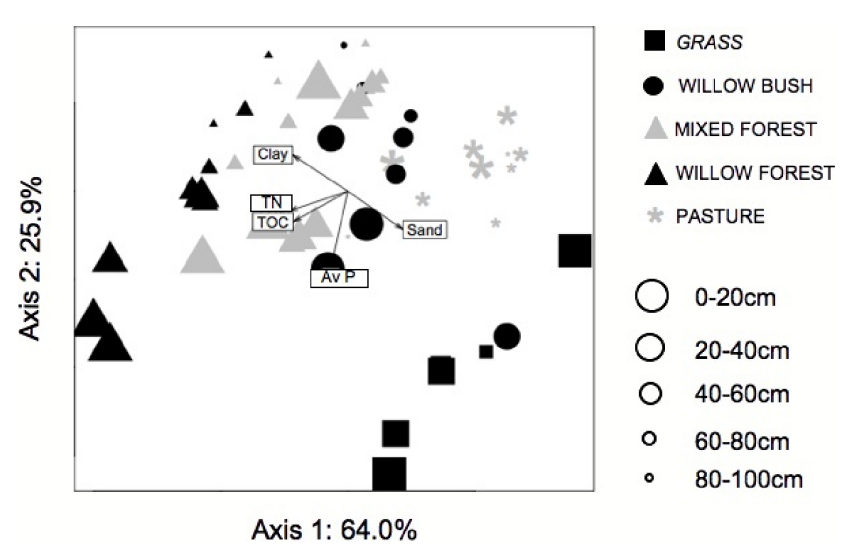

Fig. 3. Five functional process zones at the test site in the Thur River floodplain, Switzerland, with two replicates each represented on the two first axes of a PCA performed on soil physicochemical properties (total organic carbon TOC, total nitrogen TN, available phosphorus Av P, sand and clay content) measured in the soil profiles. The decreasing size of the symbols represents increasing soil depth.

$12 \mathrm{mg} \mathrm{kg}^{-1}$ at $80-100 \mathrm{~cm}$ depth. The PCA (Fig. 3) showed soil texture as the main factor separating the different FPZs, and demonstrated a generally larger lateral than vertical variation of the soil properties. It also showed that PASTURE soils were relatively homogeneous and overall most similar to the soil in WILLOW BUSH.

According to the world reference base for soil resources (IUSS Working Group WRB, 2006) the soils in GRASS, WILLOW BUSH, MIXED FOREST, and PASTURE can be classified as haplic Fluvisols (calcaric, humic) and those in WILLOW FOREST as haplic or gleyic Fluvisols (calcaric, humic, siltic). 
Table 3. Coefficients of variation (CV) for species richness and soil properties (clay content Clay, total organic carbon TOC) within different functional process zones (FPZs) of the test site in the Thur River floodplain, Switzerland $(n=4)$; mean CV for soil environmental conditions (temperature $T$, gravimetric water content WC), carbon pools (water extractable organic carbon WEOC, microbial carbon MC) and soil respiration (SR as measured, SR_T10 normalised to reference $T$ of $10^{\circ} \mathrm{C}$ ) within different FPZs $(n=4)$ at the different sampling times $(n=4)$.

\begin{tabular}{lllcccc}
\hline & GRAVEL & GRASS & $\begin{array}{c}\text { WILLOW } \\
\text { BUSH }\end{array}$ & $\begin{array}{c}\text { MIXED } \\
\text { FOREST }\end{array}$ & $\begin{array}{c}\text { WILLOW } \\
\text { FOREST }\end{array}$ & PASTURE \\
\hline Species richness & 0.25 & 0.27 & 0.11 & 0.09 & 0.07 & 0.05 \\
Clay & 0.23 & 0.43 & 0.16 & 0.12 & 0.14 & 0.20 \\
TOC & 0.37 & 0.35 & 0.19 & 0.17 & 0.06 & 0.22 \\
WC & 0.36 & 0.20 & 0.11 & 0.09 & 0.08 & 0.08 \\
$T$ & 0.005 & 0.004 & 0.002 & 0.001 & 0.002 & 0.001 \\
WEOC & 0.33 & 0.38 & 0.19 & 0.17 & 0.22 & 0.18 \\
MC & 0.41 & 0.42 & 0.31 & 0.24 & 0.31 & 0.16 \\
SR & 0.50 & 0.42 & 0.49 & 0.17 & 0.30 & 0.37 \\
SR_T10 & 0.49 & 0.47 & 0.49 & 0.17 & 0.33 & 0.38 \\
\hline
\end{tabular}

\subsection{Soil environmental conditions}

Temperature measured in GRAVEL was significantly different from all other FPZs at all seasons (Table 4). At each sampling date, either the lowest or highest temperatures were measured there, including the extremes $\left(-0.7^{\circ} \mathrm{C}\right.$, and $20.2^{\circ} \mathrm{C}$ ). Overall, there was no significant difference in $T$ among the FPZs, but in August all non-forested FPZs exhibited distinctly higher temperatures than the forested FPZs. WILLOW FOREST and GRAVEL represented the wettest and driest conditions, respectively. The spatial variability of soil moisture was highest in GRAVEL and GRASS (Table 3). Particularly high WCs were measured in August sampling, which was carried out two weeks after a major flood (see LI in Table 4), and in January when the soils were covered by snow and partially frozen.

\subsection{Carbon pools}

On average, the WEOC contents increased from GRAVEL to WILLOW FOREST, and PASTURE exhibited low WEOC contents (Table 4). WEOC was significantly higher $(P<$ 0.05) in August, and lower in April, compared to other samplings. Spatial variability of WEOC was largest in GRAVEL and GRASS (Table 3), with particularly high variability in GRASS in April and August.

Microbial $\mathrm{C}$ was higher in WILLOW FOREST than in other FPZs (Table 4). In October, MC contents were significantly lower than at the other samplings $(P<0.05)$ and highly variable. With the exception of PASTURE, spatial variability of $\mathrm{MC}$ was large (Table 3 ).

\subsection{Carbon fluxes}

Soil respiration (SR and SR_T10) was lowest in GRAVEL and highest in GRASS and WILLOW BUSH at most of the samplings, but differences were statistically not significant (Table 4). Within-patch variability of SR was generally high in all dynamic FPZs (Table 3) with hot spots in GRASS in April and August and in WILLOW BUSH in October and August. While SR values were lowest in January and highest in August, SR_T10 values varied only little with time. The $Q_{10}$ value was highest for GRAVEL, while it was similar for all other FPZs (Table 5).

All FPZs took up methane except for August. Then uptake was observed only for WILLOW BUSH and MIXED FOREST, while the other FPZs emitted methane into the atmosphere. At all samplings, plots in GRAVEL showed very low uptake or even low emissions, while MIXED FOREST exhibited the highest uptake rates of all FPZs.

\subsection{Carbon pools and fluxes as multivariate proxy of soil C dynamics}

Carbon dynamics are presented as multivariate response comprising C pools (WEOC, MC) and fluxes (SR MF), explained by soil properties and environmental conditions (LI, $T$, WC, TOC, clay). Data were clearly distributed according to sampling date (Fig. 4). The model explained $38.0 \%$ (adjusted $R^{2}$ ) of the variance of the response dataset and the two first canonical axes were significant $(P=0.001,1000$ permutations). Overall, $\mathrm{WC}$ and $T$ explained the main gradient of $\mathrm{C}$ pools and fluxes along axis 1, which separates samples of August from all others. Soil respiration was positively correlated with $T$ and negatively correlated with the number of days since the last inundation. WEOC correlated mainly with WC, whereas MC was strongly linked with clay and TOC content. 
Table 4. Mean \pm standard deviation of soil environmental conditions (days since last inundation LI, temperature $T$, gravimetric water content WC), carbon pools (water extractable organic carbon WEOC and microbial carbon MC), and fluxes (soil respiration SR as measured, SR_T10 normalised to reference $T$ of $10^{\circ} \mathrm{C}$, and methane flux MF) in the six FPZs $(n=4)$ of the test site in the Thur River floodplain, Switzerland. Samplings were repeated four times from autumn 2008 to summer 2009. Also shown are results of repeated measures ANOVA over all samplings; different lower case letters in the same row indicate significant differences $(P<0.05$; Tukey or Games-Howell post-hoc test).

\begin{tabular}{|c|c|c|c|c|c|c|c|c|}
\hline & & & GRAVEL & GRASS & $\begin{array}{l}\text { WILLOW } \\
\text { BUSH }\end{array}$ & $\begin{array}{l}\text { MIXED } \\
\text { FOREST }\end{array}$ & $\begin{array}{l}\text { WILLOW } \\
\text { FOREST }\end{array}$ & PASTURE \\
\hline \multirow[t]{8}{*}{ October 2008} & LI & days & 21 & 21 & 21 & 49 & 49 & 49 \\
\hline & $T$ & ${ }^{\circ} \mathrm{C}$ & $16.0 \pm 1.9$ & $14.5 \pm 2.9$ & $13.7 \pm 0.4$ & $13.4 \pm 0.3$ & $13.0 \pm 0.6$ & $13.5 \pm 0.2$ \\
\hline & WC & $\mathrm{g} \mathrm{kg}^{-1}$ & $171 \pm 48$ & $268 \pm 37$ & $220 \pm 34$ & $251 \pm 19$ & $302 \pm 17$ & $210 \pm 11$ \\
\hline & WEOC & $\mathrm{mg} \mathrm{kg}^{-1}$ & $127 \pm 37$ & $141 \pm 24$ & $82 \pm 15$ & $160 \pm 27$ & $164 \pm 37$ & $80 \pm 18$ \\
\hline & $\mathrm{MC}$ & $\mathrm{mg} \mathrm{kg}^{-1}$ & $132 \pm 92$ & $168 \pm 131$ & $158 \pm 119$ & $132 \pm 100$ & $227 \pm 161$ & $73 \pm 12$ \\
\hline & SR & $\mathrm{mmol} \mathrm{m}^{-2} \mathrm{day}^{-1}$ & $43 \pm 22$ & $327 \pm 39$ & $322 \pm 117$ & $194 \pm 22$ & $214 \pm 47$ & $228 \pm 86$ \\
\hline & SR_T10 & $\mathrm{mmol} \mathrm{m}^{-2}$ day $^{-1}$ & $17 \pm 3$ & $224 \pm 24$ & $203 \pm 74$ & $144 \pm 16$ & $150 \pm 26$ & $144 \pm 55$ \\
\hline & $\mathrm{MF}$ & $\mu \mathrm{mol} \mathrm{m}{ }^{-2} \mathrm{day}^{-1}$ & $-2 \pm 1$ & $-15 \pm 3$ & $-25 \pm 9$ & $-58 \pm 11$ & $-22 \pm 9$ & $-6 \pm 6$ \\
\hline \multirow[t]{8}{*}{ January 2009} & LI & days & 14 & 14 & 14 & 140 & 140 & 140 \\
\hline & $T$ & ${ }^{\circ} \mathrm{C}$ & $-0.1 \pm 0.4$ & $0.5 \pm 0.3$ & $0.3 \pm 0.4$ & $0.0 \pm 0.2$ & $0.2 \pm 0.3$ & $0.5 \pm 0.1$ \\
\hline & WC & $\mathrm{g} \mathrm{kg}^{-1}$ & $325 \pm 57$ & $296 \pm 50$ & $255 \pm 33$ & $257 \pm 26$ & $347 \pm 35$ & $252 \pm 29$ \\
\hline & WEOC & $\mathrm{mg} \mathrm{kg}^{-1}$ & $85 \pm 29$ & $143 \pm 22$ & $123 \pm 19$ & $155 \pm 38$ & $147 \pm 50$ & $116 \pm 11$ \\
\hline & $\mathrm{MC}$ & $\mathrm{mg} \mathrm{kg}^{-1}$ & $208 \pm 99$ & $178 \pm 71$ & $297 \pm 56$ & $231 \pm 42$ & $471 \pm 58$ & $331 \pm 49$ \\
\hline & SR & $\mathrm{mmol} \mathrm{m}^{-2}$ day $^{-1}$ & $8 \pm 5$ & $50 \pm 28$ & $58 \pm 37$ & $41 \pm 9$ & $55 \pm 36$ & $37 \pm 14$ \\
\hline & SR_T10 & $\mathrm{mmol} \mathrm{m}^{-2} \mathrm{day}^{-1}$ & $52 \pm 34$ & $172 \pm 98$ & $251 \pm 169$ & $128 \pm 30$ & $170 \pm 111$ & $120 \pm 44$ \\
\hline & $\mathrm{MF}$ & $\mu \mathrm{mol} \mathrm{m}{ }^{-2}$ day $^{-1}$ & $-1 \pm 3$ & $-6 \pm 7$ & $-18 \pm 13$ & $-35 \pm 19$ & $-17 \pm 9$ & $-6 \pm 5$ \\
\hline \multirow[t]{8}{*}{ April 2009} & LI & days & 5 & 21 & 112 & 240 & 240 & 240 \\
\hline & $T$ & ${ }^{\circ} \mathrm{C}$ & $15.2 \pm 2.8$ & $11.4 \pm 0.7$ & $11.0 \pm 0.7$ & $10.3 \pm 0.5$ & $11.7 \pm 0.5$ & $10.7 \pm 0.8$ \\
\hline & WC & $\mathrm{g} \mathrm{kg}^{-1}$ & $169 \pm 99$ & $204 \pm 43$ & $248 \pm 7$ & $219 \pm 26$ & $276 \pm 23$ & $152 \pm 13$ \\
\hline & WEOC & $\mathrm{mg} \mathrm{kg}^{-1}$ & $84 \pm 28$ & $96 \pm 67$ & $117 \pm 20$ & $98 \pm 16$ & $139 \pm 15$ & $94 \pm 28$ \\
\hline & $\mathrm{MC}$ & $\mathrm{mg} \mathrm{kg}^{-1}$ & $148 \pm 30$ & $135 \pm 49$ & $210 \pm 28$ & $223 \pm 29$ & $445 \pm 72$ & $208 \pm 15$ \\
\hline & SR & $\mathrm{mmol} \mathrm{m}^{-2} \mathrm{day}^{-1}$ & $91 \pm 40$ & $304 \pm 143$ & $134 \pm 47$ & $130 \pm 10$ & $178 \pm 25$ & $139 \pm 43$ \\
\hline & SR_T10 & $\mathrm{mmol} \mathrm{m}^{-2}$ day $^{-1}$ & $72 \pm 46$ & $303 \pm 179$ & $147 \pm 49$ & $135 \pm 8$ & $144 \pm 42$ & $118 \pm 46$ \\
\hline & $\mathrm{MF}$ & $\mu \mathrm{mol} \mathrm{m}{ }^{-2} \mathrm{day}^{-1}$ & $7 \pm 23$ & $-9 \pm 2$ & $-15 \pm 5$ & $-55 \pm 5$ & $-21 \pm 5$ & $-18 \pm 3$ \\
\hline \multirow[t]{8}{*}{ August 2009} & LI & days & 2 & 7 & 14 & 14 & 14 & 14 \\
\hline & $T$ & ${ }^{\circ} \mathrm{C}$ & $19.3 \pm 1$ & $18.4 \pm 0.8$ & $16.6 \pm 0.2$ & $16.3 \pm 0.1$ & $16.6 \pm 0.6$ & $18.8 \pm 0.2$ \\
\hline & WC & $\mathrm{g} \mathrm{kg}^{-1}$ & $181 \pm 70$ & $388 \pm 117$ & $348 \pm 41$ & $365 \pm 30$ & $493 \pm 44$ & $276 \pm 15$ \\
\hline & WEOC & $\mathrm{mg} \mathrm{kg}^{-1}$ & $155 \pm 60$ & $324 \pm 168$ & $418 \pm 103$ & $480 \pm 44$ & $608 \pm 131$ & $297 \pm 34$ \\
\hline & $\mathrm{MC}$ & $\mathrm{mg} \mathrm{kg}^{-1}$ & $334 \pm 90$ & $351 \pm 48$ & $306 \pm 46$ & $361 \pm 36$ & $263 \pm 66$ & $190 \pm 47$ \\
\hline & SR & $\mathrm{mmol} \mathrm{m}^{-2}$ day $^{-1}$ & $283 \pm 127$ & $432 \pm 237$ & $654 \pm 390$ & $260 \pm 67$ & $315 \pm 48$ & $345 \pm 145$ \\
\hline & SR_T10 & $\mathrm{mmol} \mathrm{m}^{-2} \mathrm{day}^{-1}$ & $50 \pm 18$ & $152 \pm 90$ & $246 \pm 148$ & $124 \pm 31$ & $147 \pm 29$ & $115 \pm 46$ \\
\hline & $\mathrm{MF}$ & $\mu \mathrm{mol} \mathrm{m}{ }^{-2} \mathrm{day}^{-1}$ & $8 \pm 8$ & $17 \pm 43$ & $-23 \pm 10$ & $-27 \pm 9$ & $52 \pm 79$ & $151 \pm 236$ \\
\hline \multirow[t]{7}{*}{ ANOVA results } & $T$ & & $\mathrm{a}$ & $\mathrm{b}$ & $\mathrm{b}$ & $\mathrm{b}$ & $\mathrm{b}$ & $\mathrm{b}$ \\
\hline & WC & & c & $a b$ & $\mathrm{bc}$ & $\mathrm{b}$ & $\mathrm{a}$ & $\mathrm{bc}$ \\
\hline & WEOC & & c & $\mathrm{bc}$ & $\mathrm{bc}$ & $\mathrm{ab}$ & $\mathrm{a}$ & $\mathrm{bc}$ \\
\hline & $\mathrm{MC}$ & & $\mathrm{b}$ & $\mathrm{b}$ & $\mathrm{b}$ & $\mathrm{b}$ & $\mathrm{a}$ & $\mathrm{b}$ \\
\hline & SR & & $\mathrm{b}$ & $\mathrm{a}$ & $\mathrm{a}$ & $\mathrm{ab}$ & $\mathrm{a}$ & $a b$ \\
\hline & SR_T10 & & $\mathrm{a}$ & $\mathrm{a}$ & $\mathrm{a}$ & $\mathrm{a}$ & $\mathrm{a}$ & $\mathrm{a}$ \\
\hline & MF & & $\mathrm{b}$ & $\mathrm{b}$ & $\mathrm{b}$ & $\mathrm{a}$ & $\mathrm{b}$ & $\mathrm{b}$ \\
\hline
\end{tabular}


Table 5. Modeled relationship between soil respiration $\left(y, \mathrm{mmol} \mathrm{CO}_{2} \mathrm{~m}^{-2} \mathrm{day}^{-1}\right)$ and soil temperature $\left(T\right.$, $\left.{ }^{\circ} \mathrm{C}\right)$ in different $\mathrm{FPZs}$ of the test site in the Thur River floodplain, Switzerland.

\begin{tabular}{lllllllll}
\hline FPZ & $y=a e^{(b T)}$ & $\mathrm{SE}_{a}$ & $\mathrm{SE}_{b}$ & $Q_{10}$ & $n$ & $F$ & $R^{2}$ & $P$ \\
\hline GRAVEL & $y=6.85 e^{(0.179 T)}$ & 0.02 & 2.1 & 6.0 & 13 & 54.7 & 0.83 & $<0.0001$ \\
GRASS & $y=51.09 e^{(0.128 T)}$ & 0.02 & 15.1 & 3.6 & 16 & 28.6 & 0.67 & $<0.0001$ \\
WILLOW BUSH & $y=43.02 e^{(0.148 T)}$ & 0.02 & 9.86 & 4.4 & 16 & 55.8 & 0.80 & $<0.0001$ \\
MIXED FOREST & $y=40.84 e^{(0.117 T)}$ & 0.01 & 3.53 & 3.2 & 16 & 235.7 & 0.94 & $<0.0001$ \\
WILLOW FOREST & $y=44.83 e^{(0.116 T)}$ & 0.02 & 8.46 & 3.2 & 16 & 56.1 & 0.80 & $<0.0001$ \\
PASTURE & $y=33.96 e^{(0.124 T)}$ & 0.01 & 6.18 & 3.4 & 16 & 77.9 & 0.85 & $<0.0001$ \\
\hline
\end{tabular}

$a$ and $b$ : regression coefficients.

$\mathrm{SE}_{a}$ and $\mathrm{SE}_{b}$ standard errors of $a$ and $b$.

$Q_{10}$ : relative increase in soil respiration upon a $T$ increase of $10^{\circ} \mathrm{C}$.

$n$ : number of individual measurements. $F, R, P: F$-value, coefficient of determination, and level of significance of the regression, respectively.

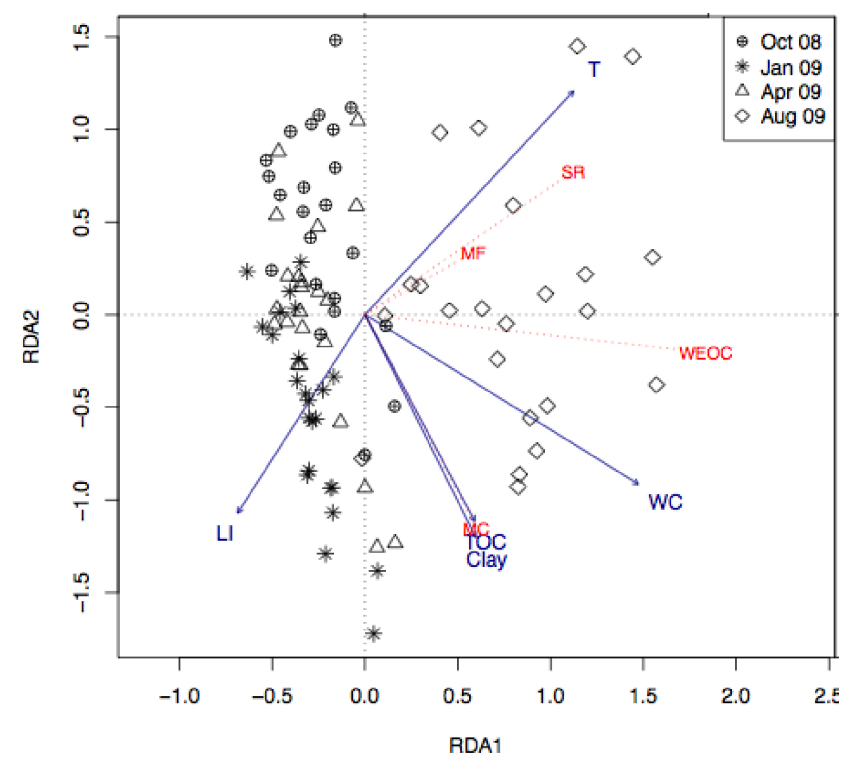

Fig. 4. RDA triplot for carbon pools and fluxes in the six functional process zones at the test site in the Thur River floodplain, Switzerland (water extractable organic carbon WEOC, microbial carbon $\mathrm{MC}$, soil respiration SR, methane flux MF) as multivariate response variables (red font), constrained by soil properties and environmental conditions (days since last inundation LI, soil temperature $T$, gravimetric water content WC, clay content Clay and total organic carbon TOC) as explanatory variables (blue font). Four soil sampling dates are represented with different symbols. Axis 1 explains $35.4 \%$ and axis $211.3 \%$ of the variance. Data were projected using scaling method 2 .

\section{Discussion}

Our data allow us (i) to relate differences between soil C dynamics in different functional process zones (FPZs) of the Thur River floodplain to differences in physicochemical soil properties on one hand and to effects of flood disturbance as driving force of a geomorphically dynamic system on the other hand, and (ii) to evaluate the relative magnitude of tem- poral variability as well as among and within-FPZ spatial heterogeneity of $\mathrm{C}$ dynamics. Based on this, conclusions about the effects of river restoration on $\mathrm{C}$ dynamics can be drawn.

\subsection{Soil properties, environmental conditions and degree of disturbance in different FPZs}

With their high carbonate content the soils at our test site are representative of young, weakly developed alluvial soils (Guenat et al. 1999). The mostly homogeneous distribution of soil properties with depth and the strong correlation between TOC and TN contents and soil texture indicates soil formation by fluvial sedimentation of homogeneous source material (Cabezas and Comin, 2010). Further homogenization can be attributed to bioturbation by earthworms. This was especially clear in the forested FPZs where earthworm biomass was highest (Fournier et al., unpublished data), most likely because of the lower frequency of inundation and fluvial dynamics (Guenat et al. 1999). On the other hand, the depth gradient of TOC and TN in WILLOW FOREST, representing an advanced stable FPZ, indicates in situ pedogenesis. Soil texture, the main factor differentiating the FPZs according to the PCA (Fig. 3), reflects the average sedimentation conditions with texture becoming finer with decreasing stream energy (Nanson and Croke, 1992). The TOC contents are within the range found in floodplain sediments of other large rivers in Europe (Graf et al., 2007; Pies et al., 2007). The low $\mathrm{C} / \mathrm{N}$ ratios and high available $\mathrm{P}$ contents (Morel et al., 1992) indicate high nutrient availability in all FPZs, which is characteristic of many river floodplains (Tockner and Stanford, 2002). The particularly high P availability in GRASS can be explained by high sedimentation rates (Steiger and Gurnell, 2003). Low $\mathrm{C} / \mathrm{N}$ values also indicate favourable conditions for organic matter degradation, which is confirmed by the observation of fast mineralisation of leaf litter in most FPZs and by the humus morphology (carbonate-rich Mull; data not shown). 
The high variability and extreme values of $T$ measured in GRAVEL are consistent with the general finding of bare gravel bars as extreme environments. The absence of stable vegetation cover to buffer temperature variations accompanied by high thermal conductivity due to low water contents explain this harshness (Tonolla et al., 2010). The differences in WC among FPZs can be explained mainly by a combined effect of precipitation, inundation frequency and water retention capacity of the soils. In particular, the maximum WC in WILLOW FOREST can be attributed largely to the finely textured soil that retains water efficiently. The additional effects of shading and water uptake by the plants on WC via evapotranspiration are not obvious from the data.

Considering the days after the last inundation (LI), the samplings carried out over the course of this study represent conditions that are typical for this site (Table 1, Fig. 2), i.e. inundation of the low-lying dynamic FPZs on a regular basis, and flooding of the entire floodplain once or twice a year. The high spatial heterogeneity of physicochemical soil properties, environmental conditions, and plant species richness in GRAVEL and GRASS (Table 3) reflects the patchy and dynamic geomorphology due to the frequent disturbance by flooding, while the low variability in the forested FPZs can be related to stable conditions leading to homogenization of properties, conditions and communities. The low variability in PASTURE can in addition be explained by its particularly homogeneous geomorphology strongly reducing erosion and sediment deposition. In agreement with the hypothesis of maximum biodiversity at intermediate levels of disturbance or connectivity (Ward et al., 1999), the pattern of plant species richness in the restored section FPZs reflects the degree of disturbance. This hypothesis predicts highest species richness in habitats characterised by intermediate inundation frequency (i.e. WILLOW BUSH), and lower diversity under high or low degrees of disturbance (i.e., GRASS and the two forested FPZs, respectively) where ruderal or competitive species dominate, respectively (in particular Phalaris arundinacea as flood tolerant species in GRASS, Foster and Wetzel, 2005). Considering the low inundation frequency, the relatively high species richness observed in PASTURE can be explained mainly by the regular harvesting, which reduces the effect of competition.

\subsection{Carbon pools and fluxes as related to soil properties, environmental conditions and disturbance in different FPZs}

The strong correlation between MC and TOC suggests Climitation of microbes, which is especially common in nutrient rich soils (Wardle, 1992). The pattern of WEOC suggests an influence of both TOC and WC. The correlation with TOC indicates similar solubility of soil organic matter across FPZs. The influence of WC is mainly a flooding effect as demonstrated by the highest WEOC contents in August after the major flood. On one hand, this pattern suggests temporar- ily increased soluble $\mathrm{C}$ pools due to input of non-structured fine soil and fresh litter along with the decreased aeration in the waterlogged soils. During soil saturation, dissolved organic matter production is expected to increase (Kalbitz et al., 2000). On the other hand, flooding has also been shown to increase the rates of enzymatic soil organic matter degradation (Wilson et al., 2011). The flood-related increase in available $\mathrm{C}$ is also reflected by increased $\mathrm{MC}$, except in WILLOW FOREST where the almost completely saturated soil suggests longer unfavourable conditions for microbial growth (Rinklebe and Langer, 2006; Unger et al., 2009).

The measured range of SR, which includes root and microbial respiration, was similar to results from other floodplains (Pulliam, 1993; Gulledge and Schimel, 2000; Pacific et al., 2008; Doering et al., 2011). The strong correlation of SR with $T$ has been commonly observed (Lloyd and Taylor, 1994; Buchmann, 2000) and explains the differences between the samplings to a large extent. The temperature dependence in terms of $Q_{10}$ values in most FPZs is similar to riparian and uphill forests (Buchmann, 2000; Doering et al., 2011), while the $Q_{10}$ value of GRAVEL is much higher than in similar systems (Doering et al., 2011). According to Pacific et al. (2008) soil $\mathrm{CO}_{2}$ efflux is determined both by $\mathrm{CO}_{2}$ production and diffusive transport in the entire soil, and soil moisture levels observed in our study would support high respiration in all FPZs most of the time. Considering this, the often highest $\mathrm{CO}_{2}$ efflux in GRASS and WILLOW BUSH can be explained on one hand by the coarse soil texture allowing optimal gas diffusion, on the other hand by the frequent and large input of available organic $\mathrm{C}$ during flooding (Doering et al., 2011). In addition, the sediment translocations during high floods may increase the content of available organic $\mathrm{C}$ also at greater depths. Together with the high spatial variability in sedimentation, this can explain the hot spots of SR observed in these two FPZs. The low SR in GRAVEL is likely due to the low fine soil content.

Consumption of atmospheric methane is largely determined by $\mathrm{CH}_{4}$ diffusion in the soil (Dörr et al., 1993), and $\mathrm{CH}_{4}$ produced in water saturated soil layers can be consumed in upper aerated soil layers (Boon and Lee, 1997). Net $\mathrm{CH}_{4}$ production can therefore be considered as an indicator of the balance between overall soil aeration and underlying $\mathrm{CH}_{4}$ production. The observed decrease of net $\mathrm{CH}_{4}$ production along the elevation gradient from GRAVEL to MIXED FOREST is in line with the aeration increasing with the average thickness of unsaturated soil, and confirms earlier studies showing a strong influence of landscape position on $\mathrm{CH}_{4}$ consumption (Burke et al., 1999; Gulledge and Schimel, 2000). This interpretation is supported by an increase in earthworm diversity (Fournier et al., unpublished data). In WILLOW FOREST, net $\mathrm{CH}_{4}$ production was higher than expected at that elevation, which suggests a relatively weak aeration, confirmed by hydromorphic features in upper soil layers (data not shown) and/or high $\mathrm{CH}_{4}$ production. These observations are both congruent with the maximum WC and 
finest soil texture found in this FPZ (Dörr et al., 1993). The high net $\mathrm{CH}_{4}$ production in the relatively high laying PASTURE, characterized by a sandy soil texture, suggests generally high $\mathrm{CH}_{4}$ production in the water-saturated layers of this FPZ. This can be explained by the relatively long travel time of infiltrating water in the channelized section of the river (Vogt et al., 2010), favouring reducing conditions in deeper soil layers.

In summary, microbial and available $\mathrm{C}$ pools are determined mainly by physicochemical soil properties with some additional effects of flooding via WC. By contrast, $\mathrm{C}$ fluxes are strongly influenced by flood disturbance, and either $T$ (SR) or geomorphology (net $\mathrm{CH}_{4}$ production).

\subsection{Temporal variability and within-FPZ heterogeneity of soil $\mathrm{C}$ pools and fluxes}

Carbon pools and fluxes as multivariate proxy of soil $\mathrm{C} \mathrm{dy-}$ namics differed more among sampling dates than among FPZs. This indicates that overall factors related to seasonality and flooding ( $T$, WC, and organic matter input) influence soil $\mathrm{C}$ dynamics more than differences in soil physicochemical properties in the test site.

The high spatial heterogeneity of all $\mathrm{C}$ pools and fluxes within GRAVEL and GRASS can be related to the variability in both soil properties and environmental conditions caused by frequent flooding disturbance. The high variability of MC in all FPZs of the restored section cannot be explained exclusively by the large-scale variability between replicate plots but might in addition be due to small-scale variability at the soil aggregate level as well as to additional heterogeneity brought by the rooting pattern and related exudation of plants. Similarly, it can be speculated that hot spots of $\mathrm{CO}_{2}$ and $\mathrm{CH}_{4}$ emissions in otherwise homogeneous FPZs (WILLOW BUSH, PASTURE) are due to small-scale heterogeneities in substrate availability and water saturation in the subsoil (Ramakrishnan et al., 2000; Sey et al., 2008).

\section{Conclusions}

This study of organic C dynamics in the Thur River floodplain revealed that in the dynamic FPZs of the restored section characterised by low TOC contents and coarse-textured soils, frequent disturbance by flood pulses temporarily and locally increased SR and the otherwise low base-levels of organic C pools. By contrast, in the stable forested FPZs, the finer texture of the soils was responsible for higher TOC contents and water retention capacity both leading to high baselevels of $\mathrm{C}$ pools. Spatial heterogeneity was smaller than the effects of major floods and seasonal $T$ differences on $\mathrm{C}$ pools and fluxes. The PASTURE FPZ stood out by (i) low $\mathrm{C}$ pools due to coarse-textured soils low in TOC, as in the dynamic FPZs, (ii) spatial heterogeneity, seasonal effects and flood disturbance, similar to the forest FPZs, and (iii) high
$\mathrm{CH}_{4}$ production that can be explained by slow travel times favouring reducing conditions.

Irrespective of the FPZ, the input of non-structured allochthonous soil material and possibly the destruction of local aggregates during flood pulses appear to be the driver for a temporary and, in dynamic FPZs, local increase of microbial activity. The related variability in available carbon or soil respiration cannot be explained by the spatial and temporal heterogeneity of bulk soil properties or the variability of environmental conditions. Our results thus confirm our first hypothesis that spatial and temporal $\mathrm{C}$ variability are affected mainly by flood disturbance. However, they also show that the temporal effects are not restricted to dynamic FPZs. The strong increase in plant biodiversity brought about by the recurrent rejuvenation of the habitats seems to support our second hypothesis, that frequent disturbance - defined as temporary and strong changes in environmental conditions and substrate availability- creates a large functional diversity. Our results therefore support recent findings that short-term inundations are important drivers of microbial habitat structure and function in floodplains (Wilson et al., 2011). Further comprehensive studies in similar as well as contrasted sites are required for generalisation of the results. In particular, since soil organic matter turnover differs between acidic and carbonate-containing soils (Walse et al., 1998), studies in sites with carbonate-free fluvial source material would be of great interest.

Based on our results, we recommend that river restoration, in order to achieve maximum recovery of ecosystem functions, should aim at creating near-natural floodplains comprising both dynamic gravel bars and stable alluvial systems. On one hand, this ensures the provision of a large diversity of habitats. On the other hand, the complex interplay of organic matter input and hot spots of both mineralisation and incomplete degradation strongly affects the potential of floodplains to store carbon, an ecosystem service of great current interest (Cierjacks et al., 2010). River widening combined with hydrological reconnection with former floodplains (from the time before channelization) as in the example presented here, is likely to be a successful recipe to achieve this goal, at least for a river characterised by pulse flooding. The Thur River example also shows that doing so on a rather small scale is sufficient to achieve a high heterogeneity of carbon pools and habitats. In cases where, in contrast to the Thur, the river is dammed upstream, this may have to be combined with controlled outflow mimicking the natural discharge regime including a few larger floods. 
Acknowledgements. This research was funded by the ETH Competence Centre of Environment and Sustainability (CCES) with additional funding from WSL and University of Neuchâtel. The RECORD project would not have been possible without the strong administrative and financial support of the environmental agencies of the Cantons Thurgau and Zurich. In particular, Canton Thurgau covered the cost of the aerial photograph shown in Fig. 1. We thank the team members of RECORD project for valuable collaboration, help and input to various parts of this study. For providing technical help for successful completion of the analyzes, we thank the technicians from the WSL units Soil Sciences, Ecosystem Boundaries, and Central Laboratory, and from EPFL. We further express our gratitute to Elena Rossel, Jean-David Teuscher, Nicolas Derungs and Benjamin Huber for help in the field and laboratory.

Edited by: P. Perona

\section{References}

Beck, T., Joergensen, R. G., Kandeler, E., Makeschin, F., Nuss, E., Oberholzer, H. R., and Scheu, S.: An inter-laboratory comparison of ten different ways of measuring soil microbial biomass $\mathrm{C}$, Soil Biol. Biochem., 29, 1023-1032, 1997.

Bishop, K., Petterson, C., Allard, B., and Lee, Y. H.: Identification of the riparian sources of aquatic dissolved organic-carbon, Environ. Int., 20, 11-19, 1994.

Boon, P. I. and Lee, K.: Methane oxidation in sediments of a floodplain wetland in south-eastern Australia, Lett. Appl. Microbiol., 25, 138-142, 1997.

Braun-Blanquet, J.: Pflanzensociologie, Springer, Wien, 1964.

Buchmann, N: Biotic and abiotic factors controlling soil respiration rates in Picea abies stands, Soil Biol. Biochem., 32, 1625-1635, 2000.

Burke, R. A., Meyer, J. L., Cruse, J. M., Birkhead, K. M., and Paul, M. J.: Soil-atmosphere exchange of methane in adjacent cultivated and floodplain forest soils, J. Geophys. Res.-Atmos., 104, 8161-8171, 1999.

Cabezas, A. and Comin, F. A.: Carbon and nitrogen accretion in the topsoil of the middle Ebro river floodplains (NE Spain): Implications for their ecological restoration, Ecol. Eng., 36, 640-652, 2010.

Cierjacks, A., Kleinschmit, B., Babinsky, M., Kleinschroth, F., Markert, A., Menzel, M., Ziechmann, U., Schiller, T., Graf, M., and Lang, F.: Carbon stocks of soil and vegetation on Danubian floodplains, J. Plant Nutr. Soil Sci., 173, 644-653, 2010.

Doering, M., Uehlinger, U., Ackermann, T., Woodtli, M., and Tockner, K.: Spatiotemporal heterogeneity of soil and sediment respiration in a river-floodplain mosaic (Tagliamento, NE Italy), Freshwater Biol., in press., doi:10.1111/j.13652427.2010.02569.x, 2011.

Dörr, H., Katruff, L., and Levin, I.: Soil texture parameterization of the methane uptake in aerated soils, Chemosphere, 26, 697-713, 1993.

Embacher, A., Zsolnay, A., Gattinger, A., and Munch, J. C.: The dynamics of water extractable organic matter (WEOM) in common arable topsoils: I. Quantity, quality and function over a three year period, Geoderma, 139, 11-22, 2007.
Field, A.: Discovering Statistics Using SPSS, 2 Edn., Sage Publications, London, UK, 2005.

Foster, R. D. and Wetzel, P. R.: Invading monotypic stands of Phalaris arundinacea: A test of fire, herbicide, and woody and herbaceous native plant groups, Restor. Ecol., 13, 318-324, 2005.

Gee, G. W. and Bauder, J. W.: Particle-size analysis, in: Methods of soil analysis. Part I. Agron. Monogr. 9, 2nd Ed., edited by: Klute, A., ASA and SSSA, Madison, WI, 383-411, 1986.

Graf, M., Lair, G. J., Zehetner, F., and Gerzabek, M. H.: Geochemical fractions of copper in soil chronosequences of selected European floodplains, Environ. Pollut., 148, 788-796, 2007.

Guenat, C., Bureau, F., Weber, G., and Toutain, F.: Initial stages of soil formation in a riparian zone: Importance of biological agents and lithogenic inheritance in the development of the soil structure, Eur. J. Soil Biol., 35, 153-161, 1999.

Gulledge, J. and Schimel, J. P.: Controls on soil carbon dioxide and methane fluxes in a variety of taiga forest stands in interior alaska, Ecosystems, 3, 269-282, 2000.

Henry, C. P., Amoros, C., and Roset, N.: Restoration ecology of riverine wetlands: A 5-year post-operation survey on the Rhone river, France, Ecol. Eng., 18, 543-554, 2002.

Hill, A. R. and Cardaci, M.: Denitrification and organic carbon availability in riparian wetland soils and subsurface sediments, Soil Sci. Soc. Am. J., 68, 320-325, 2004.

Hoehn, E. and Scholtis, A.: Exchange between a river and groundwater, assessed with hydrochemical data, Hydrol. Earth Syst. Sci., 15, 983-988, 2011, http://www.hydrol-earth-syst-sci.net/15/983/2011/.

IUSS Working Group WRB: World reference base for soil resources 2006: A framework for international classification, correlation and communication, FAO, Rome, 2006.

Kalbitz, K., Solinger, S., Park, J. H., Michalzik, B., and Matzner, E.: Controls on the dynamics of dissolved organic matter in soils: A review, Soil Sci., 165, 277-304, 2000.

Kindt, R. and Coe, R.: Tree diversity analysis, a manual and software for common statistical methods for ecological and biodiversity studies, World Agroforestry Centre (ICRAF), Nairobi, 2005.

Kuo, S.: Phosphorus, in: Methods of soil analysis: Part 3- chemical methods, edited by: Sparks, D. L., SSSA, Madison, WI, 1996.

Linde, N., Doetsch, J., Jougnot, D., Genoni, O., Dürst, Y., Minsley, B. J., Vogt, T., Pasquale, N., and Luster, J.: Self-potential investigations of a gravel bar in a restored river corridor, Hydrol. Earth Syst. Sci., 15, 729-742, 2011, http://www.hydrol-earth-syst-sci.net/15/729/2011/.

Lloyd, J. and Taylor, J. A.: On the temperature-dependence of soil respiration, Funct. Ecol., 8, 315-323, 1994.

Morel, C., Plenchette, C., and Fardeau, J.: La fertilisation phosphatée raisonnée de la culture du blé, Agronomie, 12, 565-579, 1992.

Naiman, R. J. and Décamps, H.: The ecology of interfaces: Riparian zones, Ann. Rev. Eco. Syst., 28, 621-658, 1997.

Nanson, G. C. and Croke, J.C.: A genetic classification of floodplains, Geomorphology, 4, 459-486, 1992.

Oksanen, J., Blanchet, F. G., Kindt, R., Legendre, P., O'Hara, R. B., Simpson, G .L., Solymos, P., Stevens, M. H. H., and Wagner, H.: Vegan: Community ecology package, in: $\mathrm{R}$ package version 1.17-4., 2010.

Pacific, V., McGlynn, B., Riveros-Iregui, D., Welsch, D., and Ep- 
stein, H.: Variability in soil respiration across riparian-hillslope transitions, Biogeochemistry, 91, 51-70, 2008.

Palmer, M. A., Bernhardt, E. S., Allan, J. D., Lake, P. S., Alexander, G., Brooks, S., Carr, J., Clayton, S., Dahm, C. N., Shah, J. F., Galat, D. L., Loss, S. G., Goodwin, P., Hart, D. D., Hassett, B., Jenkinson, R., Kondolf, G. M., Lave, R., Meyer, J. L., O'Donnell, T. K., Pagano, L., and Sudduth, E.: Standards for ecologically successful river restoration, J. Appl. Ecol., 42, 208$217,2005$.

Pasquale, N., Perona, P., Schneider, P., Shrestha, J., Wombacher, A., and Burlando, P.: Modern comprehensive approach to monitor the morphodynamic evolution of a restored river corridor, Hydrol. Earth Syst. Sci., 15, 1197-1212, 2011, http://www.hydrol-earth-syst-sci.net/15/1197/2011/.

Pies, C., Yang, Y., and Hofmann, T.: Distribution of polycyclic aromatic hydrocarbons (PAHs) in floodplain soils of the Mosel and Saar river, J. Soil Sediment., 7, 216-222, 2007.

Pinay, G., Clement, J. C., and Naiman, R. J.: Basic principles and ecological consequences of changing water regimes on nitrogen cycling in fluvial systems, Environ. Manage., 30, 481-491, 2002.

Pulliam, W. M.: Carbon dioxide and methane exports from a southeastern floodplain swamp, Ecol. Monogr., 63, 29-53, 1993.

R Development Core Team: R: A language and environment for statistical computing, in, $\mathrm{R}$ foundation for Statistical Computing, Vienna, 2010.

Ramakrishnan, B., Lueders, T., Conrad, R., and Friedrich, M.: Effect of soil aggregate size on methanogenesis and archaeal community structure in anoxic rice field soil, FEMS. Microbiol. Ecol., 32, 261-270, 2000.

Rinklebe, J. and Langer, U.: Microbial diversity in three floodplain soils at the Elbe river (Germany), Soil Biol. Biochem., 38, 2144 2151, 2006.

Rohde, S., Schutz, M., Kienast, F., and Englmaier, P.: River widening: An approach to restoring riparian habitats and plant species, River Res. Appl., 21, 1075-1094, 2005.

Schmider, P., Winter, D., and Lüscher, P.: Wälder im Kanton Thurgau, Mitt. Thurg. Naturf. Ges. 58, Frauenfeld, 268 pp., 2003.

Schneider, P., Vogt, T., Schirmer, M., Doetsch, J. A., Linde, N., Pasquale, N., Perona, P., and Cirpka, O. A.: Towards improved instrumentation for assessing river-groundwater interactions in a restored river corridor, Hydrol. Earth Syst. Sci. Discuss., 8, 2503-2553, doi:10.5194/hessd-8-2503-2011, 2011.

Sey, B. K., Manceur, A. M., Whalen, J. K., Gregorich, E. G., and Rochette, P.: Small-scale heterogeneity in carbon dioxide, nitrous oxide and methane production from aggregates of a cultivated sandy-loam soil, Soil Biol. Biochem., 40, 2468-2473, 2008.

Stanford, J. A., Lorang, M. S., and Hauer, F.R.: The shifting habitat mosaic of river ecosystems, Int. Ver. Theor. Angew., 29, 123136, 2005

Steiger, J. and Gurnell, A. M.: Spatial hydrogeomorphological influences on sediment and nutrient deposition in riparian zones: Observations from the Garonne river, France, Geomorphology, 49, 1-23, 2003.
Thorp, J. H., Thoms, M. C., and Delong, M. D.: The riverine ecosystem synthesis, Academic Press, Boston, MA, USA, 208 pp., 2008.

Tockner, K. and Stanford, J. A.: Riverine flood plains: Present state and future trends, Environ. Conserv., 29, 308-330, 2002.

Tockner, K., Bunn, S. E., Gordon, C., Naiman, R. J., Quinn, G. P., and Stanford, J. A.: Flood plains: Critically threatened ecosystems, in: Aquatic ecosystems: trends and global prospects, edited by: Polunin, N., Cambridge University Press, Cambridge, 45-61, 2008.

Tonolla, D., Acuna, V., Uehlinger, U., Frank, T., and Tockner, K.: Thermal heterogeneity in river floodplains, Ecosystems, 13, 727740, 2010.

Unger, I. M., Kennedy, A. C., and Muzika, R. M.: Flooding effects on soil microbial communities, Appl. Soil Ecol., 42, 1-8, 2009.

van Stokkom, H. T. C., Smits, A. J. M., and Leuven, R.: Flood defense in the Netherlands - A new era, a new approach, Water Int., 30, 76-87, 2005.

Vogt, T., Hoehn, E., Schneider, P., Freund, A., Schirmer, M., and Cirpka, O. A.: Fluctuations of electrical conductivity as a natural tracer for bank filtration in a losing stream, Adv. Water Resour., 33, 1296-1308, 2010.

Walse, C., Berg, B., and Sverdrup, H.: Review and synthesis of experimental data on organic matter decomposition with respect to the effect of temperature, moisture, and acidity, Environ. Rev., 6, 25-40, 1998.

Walthert, L., Graf, U., Kammer, A., Luster, J., Pezzotta, D., Zimmermann, S., and Hagedorn, F.: Determination of organic and inorganic carbon, delta C-13, and nitrogen in soils containing carbonates after acid fumigation with $\mathrm{HCl}$, J. Plant Nutr. Soil Sci., 173, 207-216, 2010.

Ward, J. V., Tockner, K., and Schiemer, F.: Biodiversity of floodplain river ecosystems: Ecotones and connectivity, Regul. River, 15, 125-139, 1999.

Wardle, D. A.: A comparative-assessment of factors which influence microbial biomass carbon and nitrogen levels in soil, Biol Rev. Camb. Philos., 67, 321-358, 1992.

Wilson, J. S., Baldwin, D. S., Rees, G. N., and Wilson, B. P.: The effects of short-term inundation on carbon dynamics, microbial community structure and microbial activity in floodplain soil, River Res. Appl., 27, 13, doi:10.1002/rra.1352, 2011.

Woolsey, S., Capelli, F., Gonser, T., Hoehn, E., Hostmann, M., Junker, B., Paetzold, A., Roulier, C., Schweizer, S., Tiegs, S. D., Tockner, K., Weber, C., and Peter, A.: A strategy to assess river restoration success, Freshwater Biol., 52, 752-769, 2007.

Zehetner, F., Lair, G. J., and Gerzabek, M. H.: Rapid carbon accretion and organic matter pool statilization in riverine floodplain soils, Global Biogeochem. Cy., 23, GB4004, 23, doi:10.1029/2009GB003481, 2009. 